\title{
Unilateral laterothoracic exanthem
}

\section{Ferrante S. Gragasin MD, Andrei I. Metelitsa MD}

Competing interests: None declared.

This article has been peer reviewed.

Affiliations: From the Department of Anesthesiology (Gragasin), University of Alberta, Edmonton, Alta.; and the Division of Dermatology (Metelitsa), University of Calgary, Calgary, Alta.

Correspondence to: Dr. Andrei Metelitsa, ametelit@ucalgary.ca

CMAJ 2012. DOI:10.1503 /cmaj.110315

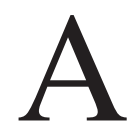
$.110315 /-/ D C 1)$. two-year-old Asian boy had a pruritic rash following resolution of a viral upper respiratory tract infection during the winter. The eruption first developed in his left axilla and then coalesced and spread down the left side of his thorax and upper part of his left arm (Figure 1). Our presumptive diagnosis was unilateral laterothoracic exanthem. We treated the eruption with moisturizers, calamine lotion and oral diphenhydramine, which partially relieved his itching. Four weeks later, the exanthem had nearly resolved (Appendix 1, available at www.cmaj.ca/lookup/suppl/doi:10.1503/cmaj

Unilateral laterothoracic exanthem, also known as asymmetric periflexural exanthem, typically affects children between one and five years of age in the winter and spring, although adults have also been affected. ${ }^{1}$ Most published reports involve white people. ${ }^{2}$ The eruption typically starts unilaterally in the axilla, but can spread centrifugally to become bilateral, making the term "unilateral" somewhat misleading. ${ }^{3}$ Despite accompanying pruritus in about $50 \%$ of patients, lichenification is not usually seen. A cause has not been definitively identified, but a close temporal relation to rhinitis, mild fever or diarrhea in $75 \%$ of patients suggests a viral link. ${ }^{2}$

Unilateral laterothoracic exanthem is commonly misdiagnosed as contact dermatitis. Its differential diagnosis is broad, including nonspecific viral exanthems, drug-related eruptions, miliaria, superficial fungal infections, scabies and atypical pityriasis rosea. The diagnosis is clinical, and laboratory investigations are generally not required. This uncommon exanthem is self-limited and usually resolves in four to six weeks with no sequelae. Treatment is symptomatic only.

\section{References}

1. Coustou D, Leaute-Labreze C, Bioulac-Sage P, et al. Asymmetric periflexural exanthem of childhood: a clinical, pathologic, and epidemiologic prospective study. Arch Dermatol 1999;135:799-803.

2. McCuaig CC, Russo P, Powell J, et al. Unilateral laterothoracic exanthem. A clinicopathologic study of forty-eight patients. J Am Acad Dermatol 1996;34:979-84.

3. Bodemer C, de Prost Y. Unilateral laterothoracic exanthem in children: A new disease? J Am Acad Dermatol 1992;27:693-6.

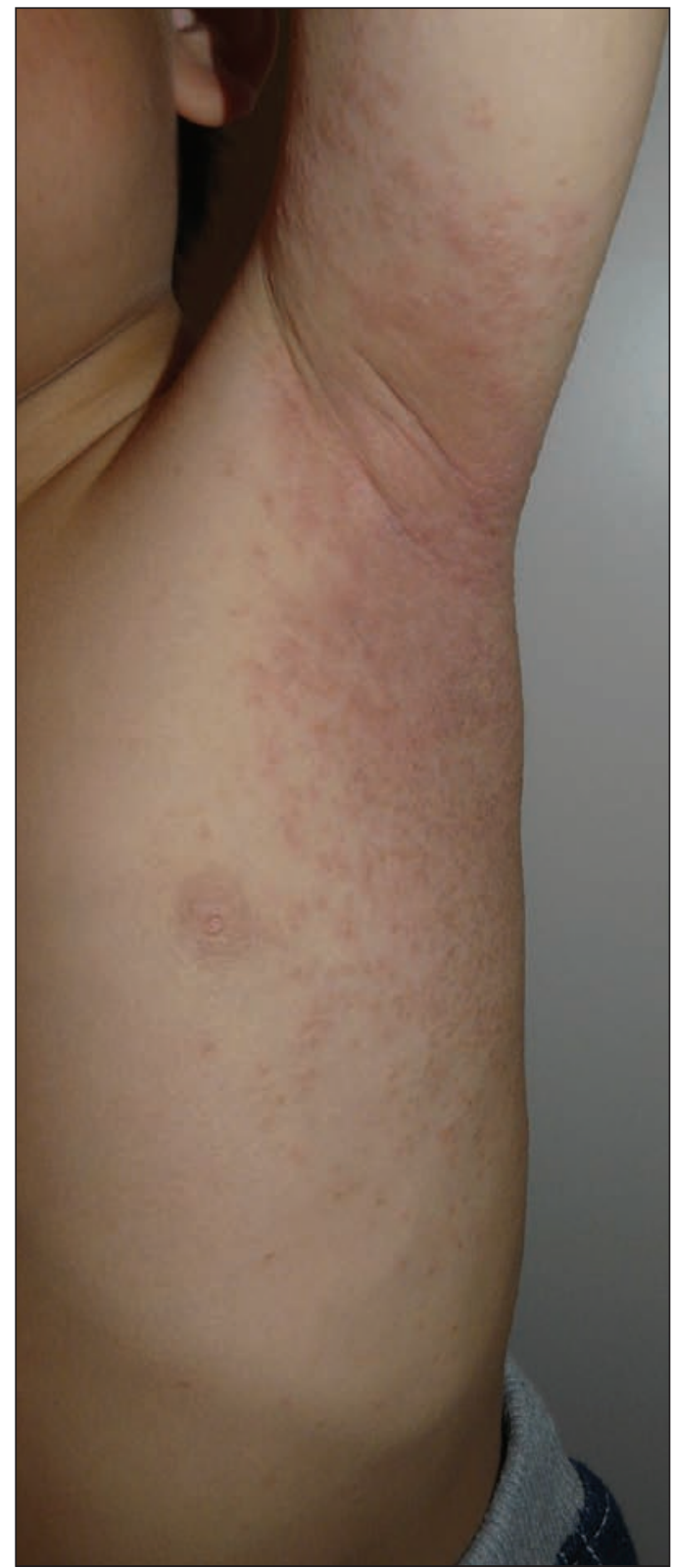

Figure 1: Unilateral skin eruption involving the thorax, axilla and arm of a two-year-old Asian boy following resolution of a viral upper respiratory tract infection. The eruption consisted of dozens of pinpoint erythematous papules surrounded by a white halo and a background of poorly demarcated eczematous plaques. 